Register of Churcima of Womer. - In the parish church registers at Preston, Lancashire, for the early part of the seventeenth century, there is a record of the churching of women. Was this a mere freak of the cleroyman's, or is there an suthority for keeping such a record? I never saw entries of this kind in any other church registers.

\section{H. FishWICK.}

Rotrenburg Famitx. - Will any of your readers conversant with German, or Continental heraldry, say what the armorial bearings are of the family of Rottonburgh, Rottnnbury, or Rattenberry, and its various ways of being spelt? They are beliered to hare been German counts. At one time a branch or branches of this family, with different coat armour, settled in the West of England about 1500 . A pedigree of one branch is preserved in the College of Arms, but no coat armour is mentioned.

George Pribearx.

The Stratrord Bust of Sirakspeare. - I went with the excursion of the British Association to Stratford-upon-Avon, and when in the chancel of Trinity Church I asked a question of the major with respect to Shalrspeare's monument. To that question I did not get a satisfactory answer. Perhaps you will permit me to ask it throngh your colunins. It is this,-Has any alteration been made in the bust of the monument since it was first erected? We have some account of a company of players giving the proceeds of a performance of Othello to recolnur the monument. We have a legend of Garrick knocking off the pen and part of the hands. We have Malone's meddling and marring, and the more recent restoration of the original colouring: but has the monument been tampered with to a greater extent? I ask this question becanse Dugdale in his Antiquities of Warvickshire, gives an engraving of the monument, which is materially different from the one now in existence. The tigures on the cornice are in different positions. The one now holding a torch is represented with an hourglass. The entablature is less ornamental, but has a dog's head orer the capital of each column. -The bust itself is entirely altered. The panel is less omamented. The face partakes of the Droeshout expression. There is no pen, no paper, no pretence of writing! The hands are holding or resting on the front of what appears to be a woolsack. The engraving is on a similar scale as the one representing the monument in the Official Guide issued by the Tercentenary Committee, but varies considerably in the depth of the monument from the top of the entablature to the commencement of the inscription. Dugdale's Antiquitics was published in 1656 , forty years after the poet's death, and the general accuracy of Dugdale's engrarings has not been impugned to my knowledge.
I again ask if the monument has been tampered with, or is Dugdale wrong? J. T. BuRgess.

Leamington.

The Name Stutrung. - Can any one explain the derivation of the family name of Stutting? It occurs very frequently in the parish registers of Scotter, co. Lincoln. K. P. D. E.

The Crescent on St. Sophrs, - In reading an interesting article in the Edinburgh Reviewo for April last on the Church and Mosque of St. Sophia, I was surprised to meet with the following statement: -

"The exterior of the dome [cupola] was originally surmounted by a stately cross, which, in the modern mosque, is replaced by a gigantic crescent fifty yards in diameter ..... the glitter of it in the sunshine is said to be visible from the summit of Mount Olympus, a distance of a hundred miles."-P. 471.

Haring often admired the exquisite symmetry of this cupola, the diameter of which cannot be more than 120 feet, it is astounding to be told that the diameter of the crescent which surmounts it is fifty yards, and I should have put it down as a misprint for five; but, on turning to Murray's Handbook, I find it stated there also to be "fifty yards in diameter," and a friend who has referred to Von Hammer, tells me that he gives the same measurement. Most probably the original blunder is Von Hammer's.

Bath Royal Literary Institution.

Tretisa : Transtation of Glanville. - It is stated in Mr. George P. Marsh's work on The Origin and History of the English Language, 1862, p. 452, that he has somewhere seen it stated that "Trevisa's manuscript of his translation of Glanvilla $D_{e}$ Proprietatibus Rerum is still in existence." Can any of your readers confirm this, and point out its present place of custody? K. P. D. E.

Sir James Stratrord Trnte, Bart. - In the old churchyard of Donnybrook, near Dublin, there is a monumental stone, in the shape of an obelisk, over the grave of Sir James Stratford Tynte, Bart. There was an inscription of considerable length, as mentioned in Brief Sketches of the Parishes of Booterstoun and Donnybrook, p. 127 (Dublin, 1861); but from the effects of the weather very little of it is now legible. Thanks, howerer, to the foresight of the late Sir William Betham, Ulster King-of-Arms, we are not left without a record of the inscription in full. It has been preserved, with transcripts of other inscriptions at Donnybrook, in rol. ii. of his MISS. Collections in the British Museum (Add. MSS. 23,684-7), and as the particulars of it will doubtless prove interesting to many readers of "N.\& Q." I hnve great pleasure in sending them. They are as follows:-

"The body of Sir James Stratford Tynte, General of the Army of Volunteers of Ireland, who died the 10th November, 1785, was here interred with military honours.

"Near this place are deposited the remains of the Right 